\title{
Profile of Students' Error in Solving Mathematics Word Problems Based on PISA Frameworks
}

\author{
Budi Murtiyasa $^{1 *}$, Sri Rejeki², Naufal Ishartono ${ }^{3}$ \\ ${ }^{I}$ Department of Mathematics Education, Universitas Muhammadiyah Surakarta, Central Java, Indonesia \\ Email: budi.murtiyasa@ums.ac.id \\ ${ }^{2}$ Department of Mathematics Education, Universitas Muhammadiyah Surakarta, Central Java, Indonesia
}

${ }^{3}$ Department of Mathematics Education, Universitas Muhammadiyah Surakarta, Central Java, Indonesia

\begin{abstract}
This study aims to analyse students' error in solving mathematics word problems based on The PISA frameworks. This is a qualitative descriptive study involving 63 students with low, moderate, and high level of mathematics achievement from 2 schools in Surakarta. The data collection was conducted using test, interview, and documentation. The data analysis was conducted in three stages namely data reduction, data display, and conclusion drawing/verification. The results indicate that based on the content, most students gave incorrect answers on the shape and space category; based on the context, most students gave incorrect answers on the occupational category; and based on the process, most students gave incorrect answers on the interpreting category. The possible factors caused of this problems are the mathematics textbooks which still lack of PISA-like problems, the teaching practices which still put mathematics as an exact and abstract subject, and the students did not familiar in solving problems which need reasoning and creativity.
\end{abstract}

Keywords: PISA frameworks, students' error, mathematics word problems

\section{Introduction}

As the demand of globalization era, Indonesian people, including students, must be prepared to participate in international competition. Various kinds of competition are held to map the quality of education in many countries all over the words. However, the results suggested that Indonesia was still on the bottom of the ranking lists.

Based on the survey conducted by Trend in International Mathematics and Science Study (TIMSS) in 2011, Indonesia was on the $36^{\text {th }}$ position from 40 participating countries [1]. The TIMMS survey conducted every four year is focus on the domain of mathematics contents and students cognitive skills. Besides that, Indonesia was on the $64^{\text {th }}$ position out of 65 countries participated in PISA-Program for International Students Assessment [2]. PISA study conducted every three years is focus on assessing students' skills in identifying, understanding, and applying mathematics in daily life.

There might be many factors causing the results of the low of students' performances on both TIMMS and PISA. A possible reason might because Indonesian students rarely face and solve problems with the characteristic of TIMMS or PISA. This study will focus on the case of PISA.

There are three components examined by PISA. The components are content, context, and process (OECD, 2013). The content is divided into four categories namely change and relationship, space and shape, quantity, and uncertainty and data. The context is divided into three categories which are personal, occupational, public, and scientific. The process is divided into three categories namely formulating, employing, and interpreting. This study used those three components and its categories to map students' error in solving mathematics word problems.

There have been several studies about Indonesian students' errors in solving PISA problems [3]-[5]. The studies found that Indonesian students mostly experienced difficulties in the early stages (comprehending and transforming) at solving contextbased task. Moreover, Wati et al.[4] claimed that the low level of students' reasoning and creativity could be the main factors of their difficulties. Besides that, gender and mathematics textbook could be the factors influencing Indonesian students' performances in PISA [6]. 
As the mathematics textbooks could be the factors of the low level of students' skills in solving PISA problems, this study aims at analyzing students' error in solving mathematics word problems based on The Program for International Students Assessment (PISA) frameworks.

\section{Methods}

This is a qualitative descriptive study involving 63 eight graders with low, medium, and high level of achievement in mathematics from two school in Surakarta. The data collection conducted using test, interview, and documentation. The test consisting six problems were translated and adapted from PISA problems 2012. The interview conducted to clarify students' answer and to identify the factors causes the errors. The documentation through the students' written works conducted to clarify the students' reasoning in answering the problems. The data collected by those three instrument helped us in interpreting and enable us to make data triangulation. Moreover, the data analysis of this study refers to the stage of qualitative data analysis by Miles and Huberman [7] which are data reduction, data display, and conclusion drawing.

\section{Result and Discussion}

The six problems translated and adapted from PISA problems in 2012, i.e. apartment purchase, garage, Helen the cyclist, charts, which cars?, and climbing mount Fuji. The problems were solve by 63 from two school in Surakarta. From the total of 63 students, six students put incorrect answers for all problems. The following Table 1 describe the number of students and their incorrect answer.

Table 1. The Number of Students' Incorrect Answer

\begin{tabular}{|c|c|}
\hline $\begin{array}{c}\text { The number of } \\
\text { students }\end{array}$ & $\begin{array}{c}\text { The number of incorrect } \\
\text { answer }\end{array}$ \\
\hline 6 & 6 \\
\hline 11 & 5 \\
\hline 15 & 4 \\
\hline 15 & 3 \\
\hline 14 & 2 \\
\hline 2 & 1 \\
\hline 0 & 0 \\
\hline
\end{tabular}

The table shows that most students give three or four incorrect answers. In addition, none of students solve all problems without incorrect answers. These following paragraphs describe students incorrect answers based on the PISA components.

\section{Students' Error Based on Content's Categories}

Based on the analysis of the answers of 63 students, it found that most students gave incorrect answers in the categories of uncertainty and data; and space and shape with about $85.71 \%$ and $77.77 \%$, respectively. In contrast, less number of students experienced errors in the categories of change and relationship and quantity with approximately $36.51 \%$. The percentages suggest that based on the content, students might be more struggling in solving problems related to uncertainty and data; and space and shape. In addition, based on qualitative analysis on students' written works, on the problem of shape and space category, most student could not find the correct orientation about the length and the width of the shape, while a few students did error calculation because they rarely find decimal for the results of their calculation.

The finding support by [4] that in students' creativity and reasoning skill might be the cause of error. Moreover, teaching practices effecting students' beliefs that mathematics should be exact might also be the cause of this error [8]. Regarding the profile of content space and shape in the mathematics textbook of K-13, the errors in uncertainty and data $(85.71 \%)$ might have relationship with the proportion of content uncertainty and data $(12.98 \%)$ in the mathematics textbooks of K-13 [9].

\section{Students' Error Based on Context's Categories}

Based on the analysis of the answers of 63 students, it found that almost all students gave incorrect answers in the categories of occupational with nearly $98.41 \%$. Whereas, the number of students experienced errors in the categories personal, societal, and scientific was nearly the same with about $49.21 \%, 58.71 \%$, and $36.51 \%$. The percentages indicate that based on the context, students might be more difficult in dealing with problems related to occupational context.

This finding was contradictory with the finding of Wijaya et al. (2014) which claimed that the highest number of errors was in the context of scientific. Moreover, regarding the profile of context occupational in the mathematics textbook of K-13, it was also contradict, because least proportion of context was also scientific $(2.88 \%)$ [9]. This might because the limitation of PISA problems for the test and the number of students participated in this test.

\section{Students' Error Based on Process Categories}

Based on the analysis of the answers of 63 students, it found the biggest number of students made error on the category of interpreting $(85,71 \%)$. While, the less number of students made error in employing $(68.73 \%)$ and formulating $(49.21 \%)$. This suggests that interpreting was more difficult for students than employing and formulating.

Regarding the K-13 mathematics textbooks, the books put more proportion for employing $(66.18 \%)$ than the other two categories which are formulating (26.80\%) and interpreting (18.55\%) [9]. However, more studies found that more students experienced difficulties in interpreting than in employing and formulating, as well 
as more students experienced difficulties in employing than in formulating [4], [5].

\section{Conclusion}

The results indicate that based on the content, most students gave incorrect answers on the shape and space category, as well as uncertainty and data; based on the context, most students gave incorrect answers on the occupational category; and based on the process, most students gave incorrect answers on the interpreting category. The possible factors caused of this problems are the mathematics textbooks which still lack of PISA-like problems, the teaching practices which still put mathematics as an exact and abstract subject, and the students did not familiar in solving problems which need reasoning and creativity. Therefore, improving the quality of those three components would be the recommendation for further studies. However, this study has limitation on both the number of problems used for the test and the number of students participated in this study. therefore, further study with more number of problems used and more number of students involved might also be recommended.

\section{Acknowledgment}

This paper is a part of the results of research "Hibah Bersaing" funded by Kementerian Riset, Teknologi, dan Pendidikan Tinggi (RISTEKDIKTI). Therefore, we acknowledge RISTEKDIKTI for the funding.

\section{References}

[1] H. Setiadi, Mahdiansyah, Rosnawati, Fahmi, and E. Afiani, Kemampuan Matematika Siswa SMP Indonesia - TIMSS. Jakarta, 2012.

[2] OECD, "PISA 2012 Results in Focus," Program. Int. Student Assess., pp. 1-44, 2014.

[3] A. Wijaya, M. Van den Heuvel-Panhuizen, M. Doorman, and A. Robitzsch, "Difficulties in solving context-based PISA mathematics tasks: an analysis of students' errors," Math. Enthus., vol. 11, no. 3, pp. 541-554, 2014.

[4] E. H. Wati, B. Murtiyasa, and U. M. Surakarta, "Kesalahan siswa SMP dalam menyelesaikan soal matematika berbasis PISA pada konten change and relationship," in KNPMP I, 2016, no. Knpmp I, pp. 199-209.

[5] Wijaya, Ariyadi, M. H. Panhuizen, Michiel Doorman, and Alexander Robitzsch, "Identifying (Indonesian) students' difficulties in solving context-based (PISA) mathematics tasks." In Innovation and Technology for Mathematics and
Mathematics Education: Prosiding International Seminar on Innovation in Mathematics and Mathematics Educatio Department of Mathematics Education, pp. 15-24. 2014.

[6] P. Burckhardt, "On the Factors Influencing Performance of Indonesian Students in PISA," 2014.

[7] Sugiyono, Metode Penelitian Kuantitatif, Kualitatif, dan R\&D. Bandung: Alfabeta, 2013.

[8] Wijaya, Ariyadi, Marja van den HeuvelPanhuizen, and Michiel Doorman, "Teachers' teaching practices and beliefs regarding contextbased tasks and their relation with students' difficulties in solving these tasks," Mathematics Education Research Journal, vol. 27, no. 4, pp. 637-662, 2015.

[9] B. Murtiyasa, S. Rejeki, and S. Murdaningsih, "An Analysis of Problems on Eight Grade of Mathematics Textbook Based on PIsa's Framework," in 3rd International Conference on Research, Implementation, and Education of Mathematics and Science (3rd ICRIEMS), 2016, pp. 305-308. 